\title{
1 \\ Australian strategic policy in the global context of the Cold War, 1945-65
}

\author{
Stephan Frühling
}

It is difficult to understate the strategic challenges that Australian governments were confronted with in the two decades after the Second World War. The period from 1945 to 1965 includes the 'first Cold War', in which the Western and communist blocs were locked in an existential strategic competition that was as yet unmitigated by any notion of détente. Moreover, for Australia this era of the 'Cold War' was very much a hot one, as its forces were continuously engaged in combat operations in different parts of Asia from 1950 to 1971. The interplay of decolonisation in Australia's neighbourhood, of threats of nationalism and communism, of the conditional nature of allies' commitment to Australia's security, and even of the revolutionary change in weapons technology, made the two decades after the Second World War a period where few certainties seemed to exist as Australia navigated its own particular version of the Cold War.

In the midst of global and regional turmoil and conflict, Australia had again to solve the basic problem of Australia's defence policy: how to defend a thinly populated continent, off the archipelago of Southeast Asia and far removed from its allied great powers, whose strategic interests and priorities by necessity lay elsewhere. The quest to solve this problem led Australia to seek close cooperation and even integration with the defence planning and posture of both Britain and the United States in Southeast 
Asia, and to play its role in the global fight against communism. At the same time, however, the consequences of decolonisation and nationalism in Indonesia presented particular challenges for Australia's strategic policy, exactly because its allies were primarily focused on the communist threat, and the centre of gravity of the global Cold War lay elsewhere.

Australia's (and New Zealand's) Cold War operations in Southeast Asia focused on a region where the Cold War was 'hot' for longest, but which was nonetheless only of third-rate importance for Australia's allies. With the notable exception of the Vietnam War, US engagement in Southeast Asia was always framed within a global strategy focused on conflict with the Soviet Union. In the 1950s in particular, the near-singular US focus on the strategic nuclear offensive as the basis of Western security was a particularly poor fit for Australia's regionally focused defence policy. By the end of the period under examination in this collection, the Kennedy Administration's new strategy of 'flexible response' proved more amenable to address Australia's concerns - and would set both countries on the fateful road to escalation in Vietnam.

\section{The origins of the Cold War}

The Cold War, between the Soviet Union and its vassal states on the one side and the free world united in a series of alliances and led by the United States on the other, began to divide the victorious coalition of the Second World War within months of the end of that momentous conflict. Demobilisation by the United States had left the Soviet Army as the dominant military power in Europe. In 1946, former British prime minister Winston Churchill warned the United States of an 'iron curtain' that had descended through the middle of Europe, ${ }^{1}$ as non-communist parties were persecuted in Poland and elsewhere in the Soviet sphere of influence. The same year, George Kennan sent his 'long telegram' from Moscow, warning of the existential and implacable threat that Soviet expansion posed for the free world. ${ }^{2}$

1 John Ramsden, 'Mr Churchill goes to Fulton', in Churchill's Iron Curtain speech fifty years later, ed. James Muller (Missouri: University of Missouri Press, 1999), 15.

2 Telegram, George Kennan to George Marshall (the 'Long Telegram'), 22 February 1946, Truman Library, Harry Truman Administration File, Elsey Papers, www.trumanlibraryinstitute.org/ this-day-in-history-2/ (accessed November 2021). 
In 1947, the United Kingdom and France renewed their alliance in the Dunkirk Treaty, and the Truman Administration replaced Britain as the sponsor of anti-communist forces in Greece and Turkey. The threat was not confined to the Atlantic area, as communist movements also took up arms in China, Tonkin, Malaya and the Dutch East Indies. But what really focused the minds of governments in London, Paris and the Hague was the impending danger to their homelands in Europe. The year 1948 saw the communist coup in Czechoslovakia, and the conclusion of the Brussels Pact between France, Britain and the Benelux countries. Even together, however, these five countries had little hope of resisting a Soviet invasion on their own. Their defence cooperation was an invitation (and plea) for the United States to overturn its adherence to George Washington's old exhortation to 'to steer clear of permanent Alliances, with any portion of the foreign World', ${ }^{3}$ and to commit its economic and military resources to the defence of Western Europe. ${ }^{4}$ The same year, the United States committed the US Air Force to defy the Soviet blockade of Berlin. One year later, it then finally pledged itself in the 1949 Washington Treaty to the defence of the members of the Brussels Pact, of Italy (as the key to the Mediterranean) and of the 'stepping stone countries' of Norway, Denmark and Portugal, which controlled vital islands in the North Atlantic: the North Atlantic Treaty Organization (NATO) was born.

America's new political commitments were translated into national defence mobilisation in 1950. In September, the Truman Administration endorsed NSC-68, which was in a sense the founding document of US and NATO strategy for the conflict with global communism. To win the Cold War, the United States would have to build up sufficient conventional and nuclear military capabilities to deter, and if necessary to defeat, Soviet attacks against the main population and industrial centres of Western Europe and East Asia. Moreover, it would need to maintain this unprecedented peacetime effort indefinitely, until the Soviet political system would eventually collapse under the weight of its internal contradictions. ${ }^{5}$

3 George Washington, 'Friends \& fellow citizens', farewell address, United States, 19 September 1796. Transcript: gwpapers.virginia.edu/documents_gw/farewell/transcript.html (accessed April 2018), p. 27.

4 David Millar, The Cold War: A military history (London: John Murray, 1997), 10-13, 16-24.

5 'A report to the National Security Council - NSC 68', 12 April 1950, Truman Library, Truman Papers, www.trumanlibrary.gov/library/research-files/report-national-security-council-nsc-68?document id=NA\&pagenumber $=1$ (accessed November 2021). 
During the final days of deliberation of NSC-68, North Korea attacked and nearly defeated the forces defending the Republic of Korea, including a small and ill-equipped US constabulary force. The Cold War had become hot, as the Korean War seemed a likely feint before the onset of global war. The United States declared a state of national emergency to assist defence mobilisation in December 1950. Even as it fought in Korea, it undertook a rapid and massive effort to create the alliance forces, standing commands, logistics and supply infrastructure that would be required for NATO to fight off the Soviet Army in Europe. ${ }^{6}$

For the following four decades, the United States would lead - and in many ways create and shape - the free world through the concerted military, economic and ideological efforts through which the Cold War was fought. The early Cold War gave rise not only to military alliances across the globe that persist to this day, including the ANZUS alliance between Australia, New Zealand and the United States, but also to the institutional underpinnings of what is today called the 'global rules-based order': the International Bank for Reconstruction and Development (today's World Bank), the International Monetary Fund, the Global Agreement on Tariffs and Trade (which became the World Trade Organization) and the Organisation for Economic Co-operation and Development that emerged from the Organisation for European Economic Cooperation to administer the US and Canadian Marshall Plan aid to Europe. ${ }^{7}$ But as these new global institutions took shape in the North Atlantic area, Britain's faraway, antipodean dominions had to navigate their own particular challenges of the Cold War.

6 Terrance J Gough, U.S. Army mobilization and logistics in the Korean War: A research approach (Washington DC: Centre of Military History, United States Army, 1987), 10; Dieter Krüger, 'Institutionalizing NATO's military bureaucracy: The making of an integrated chain of command', in NATO's post-Cold War politics: The changing provision of security, ed. Sebastian Mayer (New York: Palgrave Macmillan, 2014), 55.

7 While some of these institutions date to the 1944 Bretton Woods conference, they became key elements of the economic organisation of the free world. For a discussion of the interplay of economic and military institutions in US grand strategy during the Cold War see Richard Betts, 'U.S. national security strategy: Lenses and landmarks' (paper presented for the launch conference of the Princeton Project: Toward a New National Security Strategy, November 2004). 


\section{Australian strategic policy between Commonwealth defence and the US alliance}

As the confusing aftermath of the Second World War settled into the Cold War conflict in the northern hemisphere, Australia too was faced with disorder and uncertainty about its own security. Until the mid1950s, its main strategic challenge in this new environment was how to reconcile four different, sometimes conflicting and sometimes reinforcing, considerations: its desire for defence relations with Britain and with the United States, and whether to determine the geographic focus of its defence priorities from considerations at the global or the regional level. None of these considerations arose from a direct communist threat to Australia itself, but the way Australia responded to them would shape the way it engaged (and fought) in the Cold War during the 1950s and into the 1960s.

Before the Second World War, Australia had rested its defence on Britain's promise to send the Royal Navy to Asia in wartime. The abject failure of this 'Singapore strategy' in 1942 had demonstrated the inability of Britain to guarantee the security of Australia. But in the immediate aftermath of the war, the United States only kept a token military presence in Europe as well as Asia. While it had returned to the Philippines, Washington left the reimposition of order in the rest of Southeast Asia to the exhausted colonial powers of Britain, France and the Netherlands. ${ }^{8}$ In 1946 the Chifley Government attempted to leverage the US' interest in its wartime base on Manus Island. Australia tried, with only little chance of success, to broker a deal for ongoing use of this base on the north coast of New Guinea in return for an enduring US defence commitment to Australia. The United States preferred to divest itself of the base, rather than remain bound to a wartime coalition partner whose main asset - its geographic importance after the 1942 retreat from the Philippines - had only been of temporary relevance. ${ }^{9}$

8 Peter Dennis, 'Major and minor: The defense of Southeast Asia and the Cold War', in The Cold War and defense, ed. K Neilson and R Haycock (New York: Praeger, 1990), 138-40.

9 Roger Bell, 'Australian-American discord: Negotiations for post-war bases and security arrangements in the Pacific 1944-1946', Australian Outlook 27, no. 1 (2008): 12-33, doi.org/10.1080/ 10357717308444457. 
In the immediate aftermath of the war, there was thus little else to fall back on for Australia's strategic policy other than to look, once more, to concerted efforts of Britain and its dominions in preparing for the common defence. The 1946 Commonwealth Prime Ministers' Conference decided that the dominions should take greater responsibility for the defence of areas of strategic importance in their respective regions. The Australian Chiefs of Staff Committee proposed, in its 1947 Appreciation of the strategical position of Australia, to define Australia's region by the areas that would allow an enemy to mount air attacks against the country, which led to a focus on defending the two major access routes into Southeast Asia that the Japanese had also taken in 1942: the Philippines, to whose defence the United States remained committed, and the Malay Peninsula. ${ }^{10}$

However, the Chifley Government was far more reluctant than its military advisers to adopt Britain's threat assessments as its own - or to accept that Australia's area of strategic responsibility should be conceived of as part of the overall defence of the Empire (and hence potentially of lesser importance than the Middle East), rather than as an expression of Australia's own priorities. Britain's main possession in Southeast Asia, the Malay Peninsula, mattered for Australia primarily because of its strategic location in wartime. To Britain, however, it was the (peacetime) dollar revenues of Malaya's tin and rubber exports that made it of prime importance. London was thus careful to curtail Australia's leadership in regional security planning to the defence of sea lines of communication ${ }^{11}$ an issue whose importance had, however, also been reinforced to Australia by its recent wartime experience.

In 1948, Australia's Council of Defence, which comprised relevant members of the Cabinet as well as their main advisers, remarked that 'the designation of a potential enemy at this stage is not consistent with' government policy, and noted that 'political agreement between members of the British Commonwealth on joint strategic plans is impossible of attainment at the present time'. ${ }^{12}$ Chifley decided against Britain's requests to reinforce its forces in Hong Kong, which was threatened by communist

10 Chiefs of Staff Committee, Appreciation of the strategical position of Australia (28 October 1947). Unless referenced to the National Archives of Australia, all strategic guidance documents by the Chiefs of Staff and Defence Committees cited in this chapter are reproduced in Stephan Frühling (ed.), A history of Australian strategic policy since 1945 (Canberra: Defence Publishing Service, 2009).

11 Dennis, 'Major and minor', 140, 145.

12 Conclusions of the Council of Defence, 20 April 1948, National Archives of Australia (NAA): A816, 14/301/321. 
armies in the Chinese Civil War, or in Malaya where the 'Emergency' of communist insurrection had started the same year. Australia likewise remained very cool about Britain's request for a commitment to the defence of the Middle East. ${ }^{13}$

In December 1949, Robert Menzies returned to the prime ministership, heading a Coalition Government whose views on global security were more sympathetic with those of Britain. The Council of Defence decided that Australia was now:

to join with the other Commonwealth countries, the United States and the countries of Western Europe in organising essential deterrent forces, in building up effective defences and in working out the necessary plans, preferably on a regional basis ... [and] to resist the spread of communism by all means short of war. ${ }^{14}$

Australia should take responsibility for its home defence, for 'the overall direction and control of operations' for the defence of the ANZAM (Australia, New Zealand and Malaya) region in Southeast Asia, but its effort should conform with overall Commonwealth strategy. Hence, the government left open whether Australian forces would first be sent to the Middle East or to Southeast Asia. ${ }^{15}$

At the outbreak of the Korean War, Australia initially followed Britain's lead and did not commit forces to the conflict, but also saw an opportunity once again to seek a direct US commitment to the defence of Australia. Australia thus decided to join the war once Britain did, but exploited time zone differences to announce its decision to the United States before the government in London. The Korean War made it more urgent to settle the US-Japanese relationship through a formal peace treaty; Australia made clear the price for its agreement would be a formal US security guarantee; and hence the ANZUS Treaty was concluded in September 1951 between Washington, Canberra and Wellington - alas, with a much vaguer mutual assistance commitment than that of the Washington Treaty that had created NATO, and with little interest on the part of the United States to establish any of the joint planning or command arrangements that

13 Dennis, 'Major and minor', 144-45.

14 Defence Committee, The basic objectives of British Commonwealth defence policy and general strategy, Minute No. 86/1950, 15 June 1950, para 7.

15 Defence Committee, $A$ suitable basis for the distribution of strategic responsibility and war effort, Minute No. 89/150, 15 June 1950, paras 8, 16. 
then developed in that alliance. ${ }^{16}$ While the State Department convinced the US Joint Chiefs of Staff (JCS) to agree to staff talks, Chairman of the JCS General Omar Bradley suggested that these be held in Hawai' $i$, expressing the hope that the Australians 'will get tired of hanging around with nothing to do.. ${ }^{17}$

Somewhat ironically, the conclusion of the ANZUS Treaty thus actually reinforced Australia's focus on the defence of and through the British Commonwealth. Tensions between London, Washington and Canberra over the possibility of a US treaty with Britain's antipodean dominions that would not involve Britain itself had been ameliorated by Australia's decision in 1950 to send Royal Australian Air Force (RAAF) aircraft to Malaya to support British forces in the 'Emergency' there. ${ }^{18}$ The 1951 Radford-Collins agreement between the US and Australian navies formalised the geographic and organisational separation of peacetime surveillance and wartime protection of shipping between the Commonwealth's ANZAM area on the one hand, and the US national effort in the Pacific on the other. ${ }^{19}$ Australia sought joint planning with the United States in ANZUS, but since that was not on offer, it continued its close relationship with Britain in the hope that the United States could be brought, formally or informally, to that table.

In 1951, London also brought up again the question of an Australian commitment to the defence of the Middle East. The Menzies Cabinet decided that in wartime Australia would send the first Army and Air Force units ready for deployment to that region, and also agreed to send two understrength squadrons and ground crews to Malta in early 1952. Britain's interest in having Australian forces in the Mediterranean occurred in the context of another diplomatic tug-of-war between London and Washington: both Britain and the United States sought leadership of a new major command on NATO's southern flank, and their arguments rested on the relative size of the forces they could contribute to the region. When the RAAF units arrived in Malta, London had already accepted

16 Dennis, 'Major and minor', 144-45.

17 Henry Brands Jr, 'From ANZUS to SEATO: United States strategic policy towards Australia and New Zealand, 1952-1954', The International History Review 9, no. 2 (May 1987): 254, doi.org/ 10.1080/07075332.1987.9640442.

18 Dennis, 'Major and minor', 145.

19 Andrew Brown, 'The history of the Radford-Collins Agreement', Royal Australian Navy, Sea Power Centre, www.navy.gov.au/history/feature-histories/history-radford-collins-agreement (accessed 2018). 
that NATO's new Mediterranean Command would be headed by a US officer. ${ }^{20}$ The Australians thus served for two years as part of NATO's force structure dedicated to the defence of Europe, and notably participated in the massive 1953 air exercise 'Coronet', during which they flew from an Australian-manned improvised airfield outside Cologne. ${ }^{21}$

This was not exactly what Australia had in mind for its limited available forces. In particular, the government was conscious of the long-term strategic consequences for Australia of sacrificing the defence of the Malay Peninsula in wartime. ${ }^{22}$ Hence, Menzies asked for plans to be drawn up to send troops to Southeast Asia rather than the Middle East as early as July 1952, and for the Defence Committee to examine commitments to both regions in its first Strategic basis of Australian defence policy paper of 1953. Ultimately, the question of where to place Australia's priority rested on judgements about the likelihood of global war - in which the Middle East would have been more important than Malaya from a global perspective - and about the long-term cost for Australia of possibly losing Malaya to communism. The government accepted the committee's recommendation to give priority to ongoing 'Cold War' commitments in Southeast Asia in Australia's defence program over preparations for the possibility of global war. Moreover, Australia from now made the case to Britain for the importance of defending Malaya even in global war. ${ }^{23}$

From 1953, it was thus decided that a Third World War would not see a third Australian Imperial Force go off to fight in the Middle East. Instead, Australia sought to commit Britain and the United States to fend off a communist invasion in Southeast Asia, even in global war. Alas, here again Australia was confronted with the difficulty of managing different US and British expectations. In general, Britain was reluctant to commit to direct action against China, for fear of overcommitting Western forces and because of the vulnerability of Hong Kong. It

20 Dionysios Chourchoulis, 'High hopes, bold aims, limited results: Britain and the establishment of the NATO Mediterranean Command, 1950-1953', Diplomacy \& Statecraft 20, no. 3 (2009): 434-52, doi.org/10.1080/09592290903293779.

21 Air Power Development Centre, 'The RAAF's Malta deployment 1952-1954', Pathfinder 192 (January 2013), reproduced in Pathfinder collection 6 (2014): 105-8, at: airpower.airforce.gov.au/ sites/default/files/2021-03/PFV06-Pathfinder-Collection-Volume-6.pdf; 'R.A.A.F. wing in arduous, revealing Ruhr exercises', Sydney Morning Herald, 4 August 1953, 2.

22 Letter, McBride to Prime Minister, 6 June 1952, NAA: A816, 14/301/447.

23 Defence Committee, Strategic basis of Australian defence policy, 8 January 1953, paras 16, 20, 51; David Horner, Defence supremo: Sir Frederick Shedden and the making of Australian defence policy (St Leonards: Allen \& Unwin, 2000), 311-414. 
preferred to find accommodation with Peking over East Asian security, and refused to support joint action with the United States to support the French in Indochina. The same French difficulties did, however, also raise British concerns about the security of the Malay Peninsula. Britain did not have available in global war the three divisions that were seen as sufficient for a defence of Malaya against a full-scale invasion. But in any case, the ability to quickly occupy a defensive position at the narrow isthmus of Songkhla in southern Thailand was seen as necessary for any successful defence of the peninsula. For this task, forces had to be available in Malaya. Hence, in 1953, Australia, New Zealand and Britain agreed in principle to deploy forces from all three countries and services to form the permanent Commonwealth Strategic Reserve in Malaya. ${ }^{24}$

In contrast, the US JCS were loath to commit to the defence of any particular area in the region, preferring instead to respond to Chinese aggression with mobile air and naval forces and strikes on the Chinese mainland - and also to encourage its allies into joint action to help the French in their fight against the communist Viet Minh in Indochina, so as to prevent British pressures for assistance in the defence of Malaya later on. Hence, although the 'Five Power' talks that started in 1952 between the United States, Britain, France, Australia and New Zealand could not agree on a basic strategy for the defence of Southeast Asia, they all were interested for different reasons in a defensive arrangement for the region. The capitulation of French forces at Dien Bien Phu in 1954 made such an arrangement much less useful militarily than originally intended. But the idea retained political utility for the United States, since it would include regional countries and give Washington political cover both domestically and internationally to respond to communist aggression in the way it saw fit. Hence, Britain, Australia, New Zealand and France agreed to join the United States, Pakistan (which then included today's Bangladesh), Thailand and the Philippines as members of the Southeast Asia Treaty Organization (SEATO) in 1954, and agreed in a protocol to also consider the formally neutral countries of Laos, Cambodia and South Vietnam as relevant to their treaty commitment. ${ }^{25}$

24 David Lee, 'Australia and allied strategy in the Far East, 1952-1957', Journal of Strategic Studies 16, no. 4 (2008): 514-16.

25 Lee, 'Australia and allied strategy in the Far East', 516-22. 
Within just four years, Australia had thus become part of three formal alliance arrangements with Britain and the United States - ANZAM, ANZUS and SEATO - as well as the Five Power talks. None of them, however, achieved what it really sought: a US commitment to the defence of Southeast Asia that was underpinned by joint planning and actual force allocation. To Australia's dismay, the United States refused to use SEATO to develop the permanent alliance commands, infrastructure and plans it was creating in NATO for the defence of Europe. Moreover, Australia's commitments under SEATO were even more extensive than those of the United States, which had limited its obligations to the defence against communist threats alone. ${ }^{26}$ The only framework that resulted in genuine planning and preparations for the defence of the region remained ANZAM, but lack of US support for those arrangements would shortly cause significant embarrassment for the Australian Government. Ultimately, Australia's strategic problem was that the US defence commitment to Southeast Asia that it so much desired ran counter to the overall US strategy for the Cold War as a whole.

\section{Australian strategic policy and the Eisenhower 'New Look' strategy}

When the Eisenhower Administration assumed office in 1953, it was very concerned about the economic cost of the US defence effort in Europe and Korea. NATO had set itself significant conventional force-level goals at the Lisbon summit in 1952, which also proved beyond the means of Europe's still recovering economies. The Cold War was a global challenge, but the Soviet Union was the main adversary, and Eisenhower was looking for a better way to meet the Soviet threat that would not reduce deterrence in the short term, nor bankrupt the United States in the long term.

In a rather fortuitous coincidence, the solution to this challenge also appeared at the same time: rapid advances in almost all aspects of nuclear weapons technology. In the late 1940s, nuclear weapons had still been scarce, expensive and bulky, and the expectation was that the battles of the Third World War would be not too different from those of the second one, with atomic munitions merely providing a somewhat faster and more efficient way of conducting the strategic bomber offensive. This changed, however, 
as the cost of fissile material dropped with new gaseous diffusion plants for uranium enrichment and plutonium production reactors; breakthroughs in miniaturisation made it possible to shrink nuclear warheads from the size of a small car to that of an artillery shell; and Edward Teller and Stanislaw Ulam conceived of radiation pressure as the key to engineering a nuclear weapon primarily based on nuclear fusion, not fission: the 'thermonuclear' or 'hydrogen' bomb, first tested in 1952, opened up an age of nuclear plenty in munition numbers, warhead yields and engineering opportunities. In strategic terms, it was the early 1950s rather than the Second World War's Manhattan project that really brought about revolutionary change through nuclear weapons, ${ }^{27}$ and Eisenhower's 'New Look' strategy embraced them fully to fight the Cold War.

The long-range heavy bombers of the US Air Force's Strategic Air Command (SAC) became the main Western deterrence and warfighting instrument: a large-scale thermonuclear attack would destroy the Soviet Union as a functioning society within the first days of a new conflict. ${ }^{28}$ SAC bomber bases began to ring the Soviet Union and Eastern bloc from Greenland, over the British Isles and French Morocco, to the Eastern Mediterranean. But whereas SAC's base demands significantly expanded the geographic areas of military interest to the United States on the Soviet Union's Arctic and south-western flanks, SAC's presence in Asia was concentrated between Alaska and Guam, ${ }^{29}$ and Southeast Asia was of little relevance to the strategic bomber force.

The defence of Western Europe posed a separate problem. Thermonuclear destruction of the Soviet Union itself would not necessarily stem an attack by the Soviet Army into West Germany and beyond, and Washington had already committed to a NATO strategy of 'forward defence' as close to the Iron Curtain as possible. The solution to this particular challenge was to embrace cheap, 'tactical' nuclear weapons as a substitute for expensive, conventional manoeuvre forces. The US Army reorganised itself based on the 'Pentomic division', a structure thought to be best suited to employ nuclear weapons, and to survive on the atomic battlefield. ${ }^{30}$ Support

27 Colin Gray, Strategy for chaos: Revolutions in military affairs and the evidence of history (London: Frank Cass Publishers, 2002), 222-69.

28 Edward Kaplan, To kill nations: American strategy in the air-atomic age and the rise of mutually assured destruction (Ithaca: Cornell University Press, 2015), doi.org/10.7591/cornell/9780801452482.003.0006. 29 Kurt Wayne Schake, 'Strategic frontier: American bomber bases overseas, 1950-1960' (PhD dissertation, Norwegian University of Science and Technology, 1998).

30 Richard W Kedzior, Evolution and endurance: The U.S. Army division in the twentieth century (Santa Monica: RAND, 2000), 25. 
to NATO regional commanders' atomic strike plans assumed a higher priority for NATO air forces than defence of allied territory. ${ }^{31}$ The first nuclear-armed US Army units appeared in Germany in 1954, and nuclear cannon and missile artillery, gravity bombs, air defence missiles and landmines quickly spread throughout the force. In 1957, the United States argued for a 'nuclear stockpile' approach where US nuclear weapons would be made available to all NATO allies, so that their artillery and air defence forces could be structured for the use of nuclear firepower as well. Given US preponderance in military and political terms in the alliance at the time, NATO agreed to embrace nuclear weapons as a substitute for conventional forces. ${ }^{32}$ Hold-outs such as Norway and Denmark, which refused to allow basing of nuclear warheads on their territory in peacetime, remained under considerable US pressure for refusing to 'modernize' their forces with nuclear weapons until the early 1960s. ${ }^{33}$

In contrast, US military strategy in Asia was a derivative of its global posture. The defence of South Korea was a commitment that the United States had assumed almost by accident, and US ground forces there received tactical nuclear weapons from 1958, largely consisting of older systems that were being phased out in Europe. ${ }^{34}$ But in general there were no positions in Asia that were both as important and as immediately vulnerable as Europe was to communist invasion, before the strategic nuclear offensive would have broken the Soviet Union's back. ${ }^{35}$ The ability to inflict devastating nuclear punishment even on a country as large as China - thus negating its traditional reliance on geographic and demographic depth against external threat - was sufficient in US eyes to manage regional threats in Asia, and Washington would issue thinly veiled nuclear threats to manage the end of the Korean War, as well as the crises over Quemoy and Matsu in $1955 .{ }^{36}$ Given this global US strategy, it is no surprise that in the 1950 s the United States looked upon planning for the local defence of the Malay

31 The so-called SNOWCAT (Support of Nuclear Operations With Conventional Air Tactics) missions.

32 Simon J Moody, 'Enhancing political cohesion in NATO during the 1950s or: How it learned to stop worrying and love the (tactical) bomb', Journal of Strategic Studies 40, no. 6 (2015): 817-38, doi.org/10.1080/01402390.2015.1035434.

33 Rolf Tamnes, The United States and the Cold War in the high north (Dartmouth: Aldershot, 1991), 164.

34 Lee Jae-Bong, 'US deployment of nuclear weapons in 1950s South Korea \& North Korea's nuclear development', The Asia-Pacific Journal 7, issue 8, no. 3 (2009): 1-17.

35 A not completely inappropriate metaphor as 'broken-backed warfare' became the term commonly used in the late 1950s for a possible phase of sporadic warfare after both Western and Communist forces would have received devastating damage from widespread use of nuclear weapons. 36 John Lewis Gaddis, Strategies of containment (Oxford: Oxford University Press, 1982), 168-71. 
Peninsula, especially if it was to only employ conventionally armed forces, as something that would be of little relevance for global war, and should not distract US or allied forces from higher priorities.

In 1953, the ANZAM powers had agreed in principle on the deployment of the Commonwealth Strategic Reserve, but detailed planning still required knowledge of US atomic strike plans. These the United States would not provide, neither directly nor through SEATO. Prime Minister Menzies, however, was reluctant to announce the peacetime commitment of ground forces to the defence of Malaya without US agreement to publicly link the deployment to SEATO, and a private commitment of US military support. At a visit to the White House in March 1955, he thought he had obtained both, and soon thereafter made public Australia's commitment to the Strategic Reserve. In July 1955, however, the US chair of the JCS, Admiral Radford, provided a reply to the ANZAM plans that caused significant consternation among the Australian Government, as he reiterated that the United States would not commit specific forces to the region, that Indochina and Thailand rather than Malaya should be the first line of defence, that the United States would not exclude SEATO's Asian members from regional planning with Australia and Britain, and that given US nuclear preponderance, subversion and insurrection, rather than outright invasion, would be more likely threats in Southeast Asia. ${ }^{37}$ In effect, the United States told Australia it was preparing for the wrong war, in the wrong place and through the wrong arrangements.

Trying to use SEATO to link the United States to the ANZAM framework had failed. But although US commitment to SEATO was primarily political rather than military, the United States around the same time grew increasingly concerned about the view of the alliance's Asian members that they were being shut out from actual planning by the Anglo-Saxon powers. From late 1955, the United States thus started to share more information on its nuclear strike plans within the organisation, and agreed to increased SEATO planning activities. ${ }^{38}$ This was of course welcome to Australia, which decided to shift its focus from ANZAM and informal four-power planning to the SEATO framework, and informed Britain that it would no longer commit its forces in Malaya to the defence of the Songkhla position. ${ }^{39}$

37 Lee, 'Australia and allied strategy in the Far East', 526-27; Mathew Jones, 'The Radford bombshell: Anglo-Australian-US relations, nuclear weapons and the defence of South East Asia, 1954-57', Journal of Strategic Studies 27, no. 4 (2004): 642-49, doi.org/10.1080/1362369042000314547.

38 Jones, 'The Radford bombshell', 639-42, 650-52.

39 Lee, 'Australia and allied strategy in the Far East', 527-28. 
Britain also started to have second thoughts. As the British nuclear weapons program began to deliver operational capability, London also looked to use nuclear weapons to make economic savings in its overall defence effort. Australian planners acknowledged the usefulness of nuclear weapons for interdiction and long-range bombing, but were less convinced that they could directly substitute for conventional forces in Southeast Asia's geographic context. Nonetheless, the British 1957 Defence White Paper cut the UK military presence in Malaya by half, while promising to deploy three squadrons of nuclear-capable $V$ bombers in times of crisis instead - a posture whose strong parallels to the failed Singapore strategy of the interwar years was not lost on the Australians. ${ }^{40}$

When Australia rethought its defence strategy in 1956, it thus did so in the context of the US reliance on the strategic nuclear offensive to deter global war, increased US willingness to engage in some forms of SEATO planning, the reduction of British forces in the Far East and increased allied reliance on nuclear weapons for doubtful tactical economies. Menzies travelled to London and Washington to discuss global and regional defence strategy, and the Defence Committee argued in a new Strategic basis paper that thermonuclear deterrence had increased the likelihood of limited war, especially involving client states such as could be found in Southeast Asia. Hence, Australia decided to adopt a 'fire brigade' posture of strategic mobility that would be able to cover its SEATO commitments beyond Malaya, shorter timelines for the mobilisation of forces for limited war and greater commonality of equipment through purchases with the United States, rather than Britain. ${ }^{41}$

The Strategic basis paper argued:

If $\ldots$ adequate conventional forces are not maintained by the Western Powers to meet the requirements of cold and limited war, it may be possible for the Communist powers to achieve their aims despite the maintenance by the Western Powers of the thermonuclear deterrent. ${ }^{42}$

Australia's main contribution to the global defence effort would thus be in the form of conventional forces, but in classified guidance and public statements, the government continued to hold on to the possibility

40 Jones, 'The Radford bombshell', 653-56.

41 Lee, 'Australia and allied strategy in the Far East', 529; Jones, 'The Radford bombshell', 645-58.

42 Defence Committee, Strategic basis of Australian defence policy, 11 October 1956. 
of acquiring nuclear weapons from Australia's allies. Australia's Canberra bombers in Malaya could have deployed the new British atomic bombs. But Britain's nuclear strategy was becoming more firmly embedded in the political context of NATO and, at the 1957 Bermuda summit, in its 'special relationship' with the United States. The United States had adopted legislation to make available nuclear warheads to NATO, but Australia remained a fourth-tier ally insofar as US nuclear cooperation was concerned: after Britain, NATO members 'sharing' US warheads, and the rest of that alliance. The prospect of obtaining British or US commitments to provide Australia with nuclear charges was thus slipping even as their role increased in UK and SEATO planning for Southeast Asia, ${ }^{43}$ and in announcing the changed posture, Menzies told parliament that 'the chances are that jungle fighting will be involved'. ${ }^{44}$ National service was suspended in 1959 to release active duty personnel for deployment of the Army's new 'Pentropic' division concept - a scheme modelled on the US 'Pentomic' organisation that mostly served to provide independent confirmation of the US conclusion that this was indeed an idea more convincing in theory than in practice. ${ }^{45}$

Australia had thus settled on a defence posture that it thought more relevant to likely threats and to US policy. What remained was to pay for it. Australia's defence expenditure continued to decline as a share of GDP as the government prioritised national economic development, and the Citizen Military Forces consumed significant resources even though they were not eligible to serve beyond Australian territory. A high-ranking delegation led by the Defence Minister travelled to Washington in 1957 to request US defence assistance and industrial support. Alas, at a time when the US treasury was covering a substantial part of NATO and other allies' equipment purchases, the US National Security Council declined to do the same for Australia, as it was not seen as necessary for US global strategy to develop Australian defence or industrial capability. ${ }^{46}$

43 Wayne Reynolds, 'The wars that were planned: Australia's forward defence posture in Asia and the role of tactical nuclear weapons, 1945-1967', Australian Journal of International Affairs 53, no. 3 (1999): 297-306, doi.org/10.1080/00049919993872.

44 Commonwealth, Parliamentary Debates, House of Representatives, 19 September 1957, para 29 (Robert Menzies).

45 Jeffrey Grey, A military history of Australia, 3rd ed. (Cambridge: Cambridge University Press, 2008), 227-28.

46 Lee, 'Australia and allied strategy in the Far East', 530. 
Time, however, was on Australia's side. By accident more than by design, Australia had settled on a strategic posture that was a congruent fit with the emphasis on conventional forces that began to be advocated in the United States by General Maxwell Taylor and others, and would become an integral part of the new strategy of 'flexible response' under the new Kennedy Administration in 1961. What remained to be seen, however, was whether the increased US engagement in Southeast Asia that Australia promoted, prepared for and would soon see develop would really bring about the enduring and broad US commitment to the security of Australia and its region that it ultimately sought. In 1957, Menzies had confidently stated that in time of war it is quite certain that SEATO will establish overall commands and that our forces, by suitable arrangements, will be under them'. ${ }^{47}$ But as one prescient observer cautioned a year later:

SEATO's potential military strength depends almost wholly on American policy in a given situation, and it is difficult to see how the existence of SEATO can have material influence on that policy. ${ }^{48}$

\section{Conventional escalation: Australian strategic policy between the Communist and Indonesian threats}

In the second half of the 1950s, the main challenge for Australia's strategic policy had thus been the distance between its own concerns and US global strategy. The Malayan 'Emergency' was the only real operation, however, and Australia's defence preparations focused on limited and global wars that never happened. Writing in 1962, one particularly acerbic writer observed that Australia's defence effort was characterised by its 'sheer lack of dimension' at the global scale, 'high enough to be a burden on the economy but not high enough to provide a worthwhile defense at all'. ${ }^{49}$ By that time, however, the strategic demands on Australia had changed quite substantially compared to 1957 . Conflict with Indonesia had become an urgent concern, and the limits of direct support from the

47 Commonwealth, Parliamentary Debates, House of Representatives, 19 September 1957, para 8 (Robert Menzies).

48 W Macmahon Ball, 'A political re-examination of SEATO', International Organization 12, no. 1 (1958): 21.

49 BB Schaffer, 'Policy and system in defense: The Australian case', World Politics 15, no. 2 (January 1963): 237, 239. 
United States were made distressingly explicit, even as both Britain and the Americans looked to greater Australian contributions to security in Southeast Asia.

The first major reckoning for government of the weaknesses in the new defence posture came only two years later, when the Defence Committee submitted its 1959 version of the Strategic basis. In the intervening years, the United States had seemingly ruthlessly refused to support its close allies Britain and France in the Suez Crisis, and the Eisenhower Administration's lack of genuine military (as opposed to political) commitment to SEATO had become increasingly apparent. Both developments were particularly ominous in light of Indonesia's political-military pressure to gain control of Dutch West Papua, which still provided a geographic buffer to Australia's New Guinea territory. Jakarta skilfully toyed with Chinese and Soviet alignment, and Australia found little support from its allies as it attempted to support the Dutch. ${ }^{50}$ The Defence Committee thus recommended that Australia 'should be prepared to act independently at least for a time' in limited war against Indonesia or following global war, ${ }^{51}$ and that 'our forces ... should be designed primarily with the ability to act independently of allies'. ${ }^{52}$ For the first time, it included a statement of specifically Australian 'National Policy Objectives'. ${ }^{53}$

This was a radical shift. Since the Second World War - indeed, since Federation - it had been Australia's aim to maximise its allies' commitment of forces to Australia's region, but this was always conceived of as a problem of how to best distribute limited resources in a global conflict - be it hot or cold. Now Canberra had to face the prospect of being in a significant conflict all alone. How difficult this was to contemplate can be gleaned from the Cabinet's repeated deliberations on the 1959 Strategic basis, in which the government could not bring itself to endorse the paper, even as it ultimately accepted its substantive conclusions. ${ }^{54}$

50 Peter Edwards with Gregory Pemberton, The official history of Australia's involvement in Southeast Asian conflicts 1948-1975, vol. 1, Crises and commitments: The politics and diplomacy of Australia's involvement in Southeast Asian conflicts 1948-1965 (North Sydney: Allen \& Unwin and the Australian War Memorial, 1992), 182-207; JAC Mackie, 'Australia and Indonesia, 1945-1960', in Australia in world affairs 1956-1960, ed. Gordon Greenwood and Norman Harper (Melbourne: F.W. Cheshire, 1963), 296-304.

51 Defence Committee, Strategic basis of Australian defence policy, 12 January 1959, para 43.

52 Ibid., para 44.

53 Defence Committee, Strategic basis of Australian defence policy, 12 January 1959, para 5.

54 Frühling, A history of Australian strategic policy since 1945, 17-18. 
As it turned out, Australia's allies substantially increased their engagement in the region in the 1960s. Alas, the reasons for their engagement, and their expectations of Australian support, made Australia's challenges even more acute. The new Kennedy Administration had radically different ideas about global strategy than its predecessor. In a situation of mutually assured destruction, immediate and massive nuclear escalation ceased to be a viable approach to global war. Under the strategy of 'flexible response', Washington now sought to build up conventional forces to avoid nuclear escalation, and to keep global as well as limited war below the 'nuclear threshold' as long as possible. Moreover, communist expansion had shifted to encompass much of the developing world, including the Caribbean and Southeast Asia, and the Kennedy Administration was determined to stem this trend, including through the use of force. ${ }^{55}$ Echoing Australia's 1957 'fire brigade' posture, the Pentagon stood up a new 'Strike Command' in 1961 to provide conventional forces based in North America to regional commanders for limited war scenarios, ${ }^{56}$ and the central reserve as well as sea and airlift capabilities for rapid deployment were increased in US conventional force planning. ${ }^{57}$

Finally, Australia thus had a US Administration willing to commit forces to Southeast Asia, but this brought with it US demands to make good on Canberra's commitments under SEATO. In 1959, the communist Pathet Lao had taken up arms in Laos, and North Vietnam began its fight against the South. As SEATO discussed intervention in Laos during the first half of 1961, the Menzies Government decided on several occasions that Australia would in principle contribute forces to such an operation. By late 1961, the United States had deployed several thousand advisers to South Vietnam. ${ }^{5}$ Australia's own military involvement in the Indochina conflict began the following year, as it deployed the first advisers to Vietnam, and a squadron of Sabre fighters to its SEATO ally Thailand to deter North Vietnamese attack..$^{99}$

55 Gaddis, Strategies of containment, 198-236.

56 Robert Haffa, Rational methods, prudent choices: Planning U.S. forces (Washington DC: National Defense University Press, 1988), 75-101.

57 William W Kaufman, Planning conventional forces 1950-1980 (Washington DC: The Brookings Institution, 1982), 6-11.

58 Edwards with Pemberton, Crises and commitments, 208-36.

59 Ibid., 242. 
That same year, the West Papua crisis escalated with significant loss of life in skirmishes between Dutch and Indonesian forces. By 1962, Indonesia had become the largest non-communist recipient of Soviet arms. From Russian sources available since the end of the Cold War, it has now become apparent that the Soviet Union sent Soviet submarines and TU-16 bomber crews to participate in a large assault on the Dutch in West Papua, and to help with the planning of that operation. ${ }^{60}$ Lacking international support, the Dutch caved before this could happen, and Indonesia took control of the territory in 1963 - the same year that it began cross-border raids onto the Malay Peninsula as part of its campaign of 'Confrontation' against the creation of Malaysia.

Britain was understandably eager to employ the Commonwealth Strategic Reserve in Malaya against this threat. While Australia agreed that its forces could contribute to the defence of the Malay Peninsula against open, external attack, it also feared direct conflict with Indonesia on New Guinea, and was reluctant to expand its involvement in 'Confrontation'. The old question of whether the United States would be willing to militarily support Australia's ANZAM defence efforts, and how it would interpret its commitments under ANZUS, thus reappeared in a more urgent and immediate form. After repeated enquiries by Australia, President Kennedy and Secretary of State Dean Rusk clarified in late 1963 that the ANZUS Treaty would apply in case of open aggression by Indonesia against Australian forces in Malaysia, but that US military support would even then not necessarily be forthcoming and that it would, in any case, be limited to sea and air forces and logistic support. In addition, the United States expected Australia to consult before any Australian commitment of forces, and to avoid any measures that could be perceived as provocative. ${ }^{61}$

Faced with the need to potentially fight on three fronts - alongside Britain in 'Confrontation', to defend New Guinea against Indonesian attack, and alongside the United States in Vietnam - the limits of Australia's defence effort became painfully obvious. As early as January 1962, the Defence Committee's new Strategic basis advised the government that direct intervention in Indochina alone might require a deployment larger

60 David Easter, 'Active Soviet military support for Indonesia during the 1962 West New Guinea crisis', Cold War History 15, no. 2 (2015): 202.

61 Letter, Barwick to Menzies, 22 October 1963, 'ANZUS Treaty - United States obligations under', NAA: A7942. 
than could be sustained from Australia's regular forces. ${ }^{62}$ By September, the government asked for a reconsideration in light of the deteriorating strategic situation. A key issue was the relationship between the forward defence' commitment against communist expansion in Southeast Asia, which still centred on the Commonwealth Strategic Reserve in Malaya, and the possibility of conflict with Indonesia. In the 1963 paper on Australia's strategic position, the Defence Committee advised that the commitment to the former would increase the risk of the latter, ${ }^{63}$ but at the same time 'the degree of obligation which America feels to Australia under ANZUS could be influenced by the contributions which Australia makes to the common defence'. ${ }^{64}$

Hence, Australia's defence integration through ANZAM was a main reason for conflict with Indonesia; Australia's hope for US support based on the ANZUS Treaty rested on its willingness to support SEATO; to which Australia's ANZAM commitment was still its most important contribution. Australian strategic policy was caught in a dilemma from which there seemed to be no obvious way out. Cabinet thus confirmed that

Australia's military strategy is based on the maintenance of a forward position in South-East Asia ... and [decided] to accept the risk that thereby we may cause tension in our relations with Indonesia. ${ }^{65}$

As a consequence, it

agreed that there should be an increase in the present scale of defence programming ... not only to ensure the security of the Australian mainland and East New Guinea, but also to enable us to make an effective and sustained contribution in South-East Asia and to present a deterrent to possible activities by Indonesia inimical to our strategic interests. ${ }^{66}$

Military expenditure was increased, the strength of the Army was raised, Australia purchased additional helicopters and transport aircraft, 40 additional Mirage fighters, and ordered 24 F-111 to replace the ageing

62 Defence Committee, Strategic basis of Australian defence policy, 25 January 1962, paras 22, 54.

63 Defence Committee, Australia's strategic position, 4 February 1963, paras 17, 18, 30.

64 Ibid., para 25.

65 Cabinet Decision No. 675, 5 March 1963, NAA: A1945, 83/2/8.

66 Ibid. 
Canberra bombers. ${ }^{67}$ It also ordered a third guided missile destroyer which the new US Administration now agreed to subsidise with interest-free loans, as it had done with the previous two ships in $1961 .^{68}$

The next Strategic basis paper of October 1964 followed more substantial Indonesian landings in Malaya, as well as the Gulf of Tonkin incident. It foreshadowed commitments in Vietnam 'on a scale which could approach the proportions of a limited war', concomitant with the need to potentially fight and deter Indonesia in Malaysia as well as in New Guinea, and recommended further increases in the size and capability of the defence force. ${ }^{69}$ Decades later, then Secretary of the Department of External Affairs Sir Arthur Tange would recall the pressures facing Australia's ministers at the time:

I retained a memory of the blunt warning that I heard [US Secretary of State] Dean Rusk give to [Foreign Minister] Hasluck in 1964. During the discussion of worsening relations between Malaysia and Indonesia, Hasluck volunteered to inform the Americans before committing Australian forces in support of Malaysia. Responding to the inherent assumption that such a deployment would trigger an expectation of American military support, Rusk pointedly said that the United States would expect that Australia would have introduced conscription and full mobilisation, and added 'there is no residuum of responsibility falling on the United States that is reached at a certain point'. ${ }^{70}$

Within weeks of considering the 1964 Strategic basis, the government reintroduced conscription, for the second time since the Second World War. In January 1965, it deployed one battalion to counter Indonesian incursions in Borneo and, in June 1965, the first battalion went into Vietnam. Australia’s Cold War had well and truly become a hot one.

67 Alan Stephens, Going solo: The Royal Australian Air Force, 1946-1971 (Canberra: Australian Government Publishing Service, 1995), 47-48; Grey, A military history of Australia, 229.

68 Steven Paget, 'On a new bearing: The reorganized Royal Australian Navy at war in Vietnam', The Mariner's Mirror 101, no. 3 (2015): 288-90, doi.org/10.1080/00253359.2015.1054686.

69 Defence Committee, Strategic basis of Australian defence policy, 15 October 1964, paras 45, $67,70,78$.

70 Sir Arthur Tange, Defence policy-making: A close-up view, 1950-1980, ed. Peter Edwards (Canberra: ANU E Press, 2008), 40, doi.org/10.22459/DPM.07.2008. 


\section{Conclusion}

In 1965, the heaviest fighting and most Australian casualties in Vietnam had yet to occur. And yet, the replacement of Indonesia's President Sukarno by General Suharto late that year meant that the nightmares of a three-front conflict, which had occupied Australia's government and senior defence advisers in the early 1960s, did not come to pass. The end of 'Confrontation' also spelled the end of Britain's military commitment to Southeast Asia, which the conflict with Indonesia had given an unexpected but temporary reprieve. The logic of Australia's 'forward defence' now solely rested on the policy of the United States, but Washington's decision not to burden itself with the SEATO framework in Vietnam made clear that Australia's hope for an enduring US commitment to the region was as misplaced as before.

As early as November 1966, the Defence Committee endorsed the view that Southeast Asia would not quickly fall to communism, that there would be warning time available of a significant threat, and that within a force structure designed for limited war a 'potential for expansion' should now also be provided. ${ }^{71}$ In 1968, a new Strategic basis paper broke with the 'domino theory' that the fall of one country to communism would inexorably bring the communist threat to Australia's doorstep, and started to make numerous references to the 'defence of Australia' as a future consideration. As the spectre of the communist threat receded, so did the need for, and viability of, Australia's posture of 'forward defence'. What remained was to prepare for the possibility of future conflict with Indonesia, which would become the main preoccupation for Australian defence policy in the era of 'self-reliance' after Vietnam. Australia continued to support its allies politically in the Cold War, through the Joint Facilities, and through maritime surveillance in the Indian Ocean, South Pacific and Southeast Asia; but as the central focus of strategic policy, Australia's Cold War ended with the war in Vietnam.

When the Menzies Government committed to the forward defence policy in the 1950s, it was not doing the bidding of its 'great and powerful friends'. Indeed, Britain had good reason to gripe about the limitations and conditions that Australia placed on its commitment to the defence

71 Defence Committee, Interim review of the Strategic basis of Australian defence policy, 24 November 1966, NAA: A1838, TS677/3 PART 10, paras 39, 41, 42, 51. 
of Malaya at Sogkhla in the 1950s, and against Indonesia in the 1960s. Until the commitment of major Australian forces to Vietnam, the way in which Australia went about trying to prepare for the defence of Southeast Asia, politically as well as militarily in the ANZAM and SEATO frameworks, also never aligned with US preferences and perspectives. Australia sought a US strategic commitment to the region that was institutionally embedded and enduring, as well as politically significant and militarily meaningful. In the 1950s it achieved the former but not the latter, in Vietnam the latter but not the former. Was Australia's strategic policy between 1945 and 1965 an abject failure?

It is not difficult, but also ultimately irrelevant, to poke holes in the perception by Australian leaders of the time that Southeast Asia was in direct and immediate danger of falling to communism through outright invasion, or through an inexorable fall of the 'dominos' to communist insurrection. What matters is that this perception was real, and that the British and US priority on Europe and Northeast Asia meant that Australia was faced, throughout this time, with a strategic problem to which there were no good solutions. Some aspects of Australia's attempts to bind Britain and the United States to the defence of Southeast Asia seem almost quixotic when placed in the global context of their time. But the Australians of the 1950s and early 1960s were battling not just the threat of contemporary communism, but also the spectre of 1942 and the fall of Singapore. The war in Vietnam would vanquish both, through its regional-strategic as well as domestic-political consequences. In that sense, for Australia's strategic policy the year of 1965 marked not just the beginning of the end of Australia's Cold War, but also of the war that had come before. 
This text is taken from Fighting Australia's Cold War: The Nexus of Strategy and Operations in a Multipolar Asia, 1945-1965, edited by Peter Dean and Tristan Moss, published 2021 by ANU Press, The Australian National University, Canberra, Australia.

doi.org/10.22459/FACW.2021.01 